\title{
RESTRICTION FRAGMENT LENGTH POLYMORPHISMS ON THE q24-q28 REGION OF X CHROMOSOME AMONG JAPANESE POPULATION
}

\author{
Takashi Taga, ${ }^{1}$ Wataru Shirahase, ${ }^{1}$ Morimi Shimada, ${ }^{1}$ \\ Kiyoshi Kurokawa, ${ }^{2}$ and Hisao Ueyama ${ }^{2, *}$ \\ Departments of ${ }^{1}$ Pediatrics and ${ }^{2}$ Medical Biochemistry, Shiga University of Medical Science, \\ Seta, Otsu 520-21, Japan
}

\begin{abstract}
Summary Restriction fragment length polymorphisms were studied among the Japanese population using 12 polymorphic DNA probes on the q24-q28 region of $X$ chromosome. The frequency distribution for probes p22-33, p482.6a, p43-15, 52A, pPM101, cX33.2 and cpx234, was the same as that for Caucasians, and that for probes 4D-8 and St14-1 (MspI) was slightly different $(\mathrm{p}<0.05)$. However, it was quite different $(\mathrm{p}<0.01)$ for probes p114.12, St14-1 (TaqI), 36B-2 and MN12. Probe p114.12 showed no Hind III polymorphism for the Japanese people. On the contrary, probe MN12, which has a low PIC value (0.15) for Caucasians, was found to be useful for Japanese (PIC value $=0.50$ ). These results suggest that 7 DNA probes (p482.6a, p43-15, 52A, St14-1, pl14.12 (BclI), 36B-2 and MN12) are useful (PIC >0.42) for linkage analysis of X-linked disease in Japan.
\end{abstract}

Key Words RFLP, X chromosome

\section{INTRODUCTION}

Restriction fragment length polymorphisms (RFLPs) are powerful tools for carrier detection and prenatal diagnosis of inherited diseases, especially of genetic disorders with unidentified biochemical lesions such as Huntington's disease and cystic fibrosis (Guesella et al., 1983; Tsui et al., 1985).

We have several families of adrenoleukodystrophy (ALD), which shows an $\mathrm{X}$-linked inheritance. The disease is one of the most frequent neurodegenerative disorders, and its defective gene is localized on the distal end of the long arm of X chromosome (Migeon et al., 1981). The chromosomal region is very important, because the affected gene of quite a few heritable disorders is known to be around

Received March 10, 1989; revised version received May 1, 1989; Accepted May 11, 1989

* To whom correspondence should be addressed. 
$\mathrm{Xq} 26-\mathrm{Xq} 28$, e.g., hemophilia $\mathrm{A}$ and $\mathrm{B}$, the fragile $\mathrm{X}$ mental retardation syndrome, G6PD deficiency, Lesch-Nyhan syndrome, color blindness and so on. Many polymorphic DNA probes have been reported on the $\mathrm{X}$ chromosome, but the usefulness of the probes for genetic linkage analysis is determined mainly by their frequency of RFLPs, which may be different among human races as described previously (Antonarakis et al., 1985; Waincoat et al., 1986; Paul et al., 1987). In this communication, we present frequencies of RFLPs among the Japanese population for 12 probes on the $\mathrm{q} 24-\mathrm{q} 28$ region of $\mathrm{X}$ chromosome.

\section{MATERIALS AND METHODS}

High-molecular-weight DNA was extracted and purified from peripheral blood leukocytes of unrelated Japanese individuals. The DNA (5 $\mu \mathrm{g}$ each) was digested with appropriate restriction enzymes, and then separated by gel electrophoresis on 0.7 or $1.0 \%$ agarose in TAE buffer $(0.04 \mathrm{M}$ Tris-acetate- 2 mM EDTA, pH 7.8$)$, and transferred to a nitrocellulose membrane filter (NitroPlus 2000, Micron Separations Inc.) (Southern, 1975) using Vacuum Blotting System (LKB 2016 VacuGene, Pharmacia). The DNA probes were labeled by using Random Primer DNA Labeling Kit (Takara, Japan) and $\left[\alpha^{-32} \mathrm{P}\right] \mathrm{dCTP}(\mathrm{ICN})$ (final specific activity $=10^{9}$ $\mathrm{dpm} / \mu \mathrm{g}$ ). Hybridization was carried out as described (Wion et al., 1986), and then the filter was washed briefly in $6 \times \mathrm{SSC}(20 \times \mathrm{SSC}: 3 \mathrm{~m} \mathrm{NaCl}-0.3 \mathrm{M}$ sodium citrate), once in $2 \times \mathrm{SSC}$ containing $0.1 \%$ sodium dodecyl sulfate (SDS) for $30 \mathrm{~min}$ at room temperature, and twice in $0.1 \times \mathrm{SSC}$ containing $0.1 \% \mathrm{SDS}$ for $60 \mathrm{~min}$ at $65^{\circ} \mathrm{C}$. Autoradiography was carried out at $-20^{\circ} \mathrm{C}$ for $1-4$ days.

The DNA probes used were kindly supplied by Dr. J.L. Mandel (St14-1), Dr. K.E. Davies (MN12) and Dr. P.L. Pearson (cX33.2). The other probes were obtained from American Type Culture Collection (ATCC). The probe p482.6a contains a $1.1 \mathrm{~kb} E c o \mathrm{RI} / \mathrm{Sst} \mathrm{T}$ fragment derived from the original $9.6 \mathrm{~kb}$ insert in $\mathrm{p} 482.6$ (Wion et al., 1986). The probe $36 \mathrm{~B}-2(2.2 \mathrm{~kb}$ HindIII fragment) is next to the probe $6 \mathrm{~A}-1$ on the human genome and can detect the same TaqI polymorphism as $6 \mathrm{~A}-1$ without a constant band of $3.5 \mathrm{~kb}$. The probe pPM101 contains a $2.3 \mathrm{~kb}$ EcoRI fragment derived from the original $18.0 \mathrm{~kb}$ insert in $07-03$.

\section{RESULTS AND DISCUSSION}

Table 1 summarizes the results of RFLP analysis with 12 DNA probes. We analyzed three other probes (cx38.1, p 22.7 , and DX13), which are not included in the table. Probe cx38.1 seemed to contain repeated sequences, and probe $\mathrm{p} \lambda 2.7$ gave no EcoRI polymorphisms. The frequency of RFLP detected with DX13 has been reported by Suzuki et al. (1988), and we obtained about the same frequency $(5.4 \mathrm{~kb}: 2.0 \mathrm{~kb}=27: 73)$.

In the case of probe $\mathrm{p} 482.6$, which is derived from coagulation factor VIII 
Table 1. RFLP for DNA probes on the q24-q28 region of X chromosome.

\begin{tabular}{|c|c|c|c|c|c|c|}
\hline \multirow{2}{*}{ Probe } & \multirow{2}{*}{\multicolumn{2}{|c|}{$\begin{array}{l}\text { Restriction } \\
\text { enzyme }\end{array}$}} & \multicolumn{2}{|c|}{ Japanese } & \multicolumn{2}{|c|}{ Previous reports } \\
\hline & & & Size (kb) & Frequency (n) & Size (kb) & Frequency \\
\hline \multirow[t]{2}{*}{$\mathrm{p} 43-15$} & $B g I I I$ & & 9.5 & $0.32(23)$ & 9.5 & 0.19 \\
\hline & & & 6.0 & $0.68 \quad(49)$ & 6.0 & 0.81 \\
\hline \multirow{2}{*}{$\mathrm{p} 22-33$} & $\operatorname{Taq} \mathbf{I}$ & & 20.0 & $0.13(2)$ & 20.0 & 0.17 \\
\hline & & & 11.0 & $0.87 \quad(42)$ & 11.0 & 0.83 \\
\hline \multirow{2}{*}{$36 \mathrm{~B}-2$} & $\operatorname{Taq} \mathbf{I}$ & & 7.0 & $0.52(26)$ & 7.0 & 0.33 \\
\hline & & & 5.0 & $0.48(24)$ & 5.0 & 0.67 \\
\hline \multirow[t]{2}{*}{$\operatorname{cpX} 234$} & $\operatorname{Taq} \mathbf{I}$ & & 3.2 & $0.20(10)$ & 3.2 & 0.17 \\
\hline & & & 1.1 & $0.80(40)$ & 1.1 & 0.83 \\
\hline \multirow[t]{2}{*}{$52 \mathrm{~A}$} & $\operatorname{Taq} \mathrm{I}$ & & 1.6 & $0.69(33)$ & 1.6 & 0.50 \\
\hline & & & 1.3 & $0.31(15)$ & 1.3 & 0.50 \\
\hline \multirow[t]{2}{*}{ pPM101 } & BanII & & 4.2 & $0.10(5)$ & 4.2 & 0.19 \\
\hline & & & 2.4 & $0.90(47)$ & 2.4 & 0.81 \\
\hline \multirow[t]{2}{*}{$4 \mathrm{D}-8$} & $M s p \mathrm{I}$ & & 25.0 & $0.94(47)$ & 25.0 & 0.82 \\
\hline & & & 7.8 & $0.06(3)$ & 7.8 & 0.18 \\
\hline \multirow[t]{4}{*}{ p114.12 } & BclI & & 1.2 & $0.33(16)$ & 1.2 & 0.59 \\
\hline & & & 0.9 & $0.67(32)$ & 0.9 & 0.41 \\
\hline & HindIII & & 2.7 & $1.00(98)$ & 2.7 & 0.87 \\
\hline & & & & & 2.6 & 0.13 \\
\hline \multirow[t]{11}{*}{ St14-1 } & MspI & & 2.3 & $0.56(30)$ & 2.0 & 0.70 \\
\hline & & & 1.8 & 0.44 (24) & 1.6 & 0.30 \\
\hline & $\operatorname{Taq} \mathrm{I}$ & 1 & 6.6 & $0.00(0)$ & 6.6 & 0.01 \\
\hline & & 2 & $5.4,5.2$ & $0.00(0)$ & $5.4,5.2$ & 0.04 \\
\hline & & 3 & 4. 8 & 0.02 (1) & 4.8 & 0.12 \\
\hline & & 4 & 4.5 & $0.15(8)$ & 4.5 & 0.36 \\
\hline & & 5,6 & $4.3,4.1$ & $0.06(3)$ & 4. $1,4.0$ & 0.21 \\
\hline & & 7 & 3.9 & $0.37(20)$ & 3.9 & 0.11 \\
\hline & & 8 & 3.4 & $0.40(22)$ & 3.4 & 0.16 \\
\hline & $\operatorname{Taq} \mathrm{I}$ & $\alpha$ & 5.5 & $0.52(28)$ & 5.5 & 0.92 \\
\hline & & $\beta$ & 4.1 & $0.48(26)$ & 4. $1,1.4$ & 0.08 \\
\hline \multirow[t]{2}{*}{ p482.6a } & \multirow{2}{*}{\multicolumn{2}{|c|}{$X b a \mathrm{I} / K p n \mathrm{I}$}} & 6.2 & $0.33(18)$ & 6.2 & 0.41 \\
\hline & & & 4.8 & $0.67(36)$ & 4.8 & 0.59 \\
\hline \multirow[t]{2}{*}{ MN12 } & $B g l \mathbf{I}$ & & 10.0 & $0.46(24)$ & 10.0 & 0.08 \\
\hline & & & 8.0 & $0.54(28)$ & 8.0 & 0.92 \\
\hline \multirow[t]{2}{*}{ cX33.2 } & ApaL1 & & 12.0 & $0.26(14)$ & 12.0 & 0.36 \\
\hline & & & 8.3 & $0.74(39)$ & 8.3 & 0.64 \\
\hline
\end{tabular}

Vol. 34, No. 2, 1989 


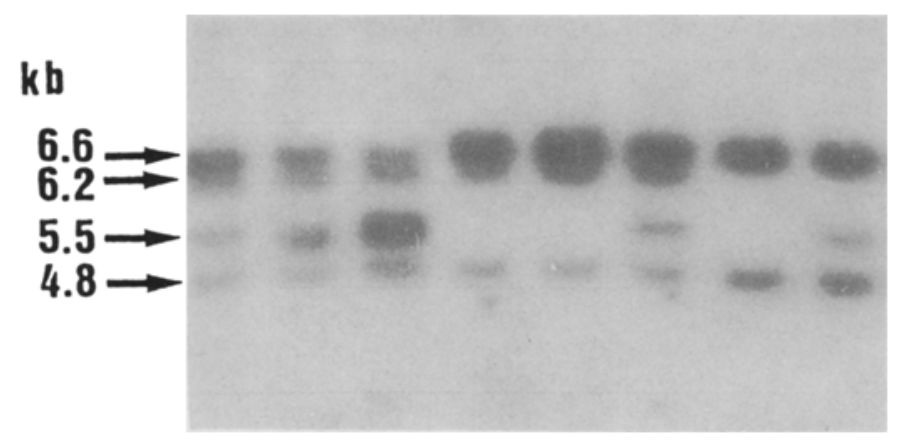

Fig. 1. Polymorphic pattern of $\mathrm{Xbal} / \mathrm{KpnI}$ fragments hybridizing to the $\mathrm{p} 482.6 \mathrm{a}$ probe. Japanese (female) DNAs were digested with $X b a \mathrm{I}$ and $K p n \mathrm{I}$ and analyzed by blot hybridization. In addition to the polymorphic bands $(6.2 \mathrm{~kb}$ and $4.8 \mathrm{~kb})$ and the constant (for Caucasians) band $(6.6 \mathrm{~kb})$, a $5.5 \mathrm{~kb}$ band is seen in some Japanese.

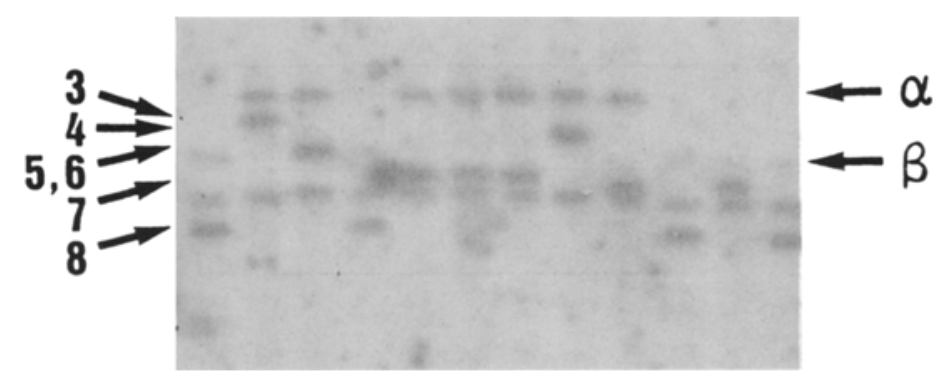

Fig. 2. Polymorphic pattern of TagI fragments hybridizing to the St14-1 probe. Japanese (male) DNAs were digested with TaqI and analyzed by blot hybridization. There is a tight association between alleles 8 and $\beta$.

gene, a $5.5 \mathrm{~kb}$ band was found in about a half of the XbaI/KpnI-digested DNAs we examined (Fig. 1). The previous study (Wion et al., 1986) did not refer to this band but to the $6.6 \mathrm{~kb}$ band, the origin of which is unknown. About $30 \%$ of the males showed both bands, about $60 \%$ showed only the $6.6 \mathrm{~kb}$ band, and the others showed only the $5.5 \mathrm{~kb}$ band. Females showed more intense signals than males. If we assume that these bands are from $X$ chromosome, then the calculated frequencies among females are 63,36 and $1 \%$, respectively; these are comparable with the actual frequencies $(55,44$ and $5 \%$, respectively). Therefore, these hybridizing regions may also be derived from the $\mathrm{X}$ chromosome. Wion et al. (1986) reported that no examples were found of the combination of large $B c l I$ allele $(1.2 \mathrm{~kb}$ detected with $\mathrm{p} 114.12)$ and small $X b a \mathrm{I} / K p n \mathrm{I}$ allele $(4.8 \mathrm{~kb}$ detected with $\mathrm{p} 482.6 \mathrm{a})$. We did not detect this combination, either.

DNA probes, the RFLP frequencies of which showed a marked difference from those reported for Caucasians, are as follows: p114.12, St14-1, 36B-2, and MN12. 
p114.12: The HindIII polymorphism was not observed for the probe p114.12; only the $2.7 \mathrm{~kb}$ band was found in our study in contrast to two bands in the previous report ( 2.7 and $2.6 \mathrm{~kb}$ ). Therefore, the DNA probe p114.12, derived from coagulation factor VIII gene, may be useless for the Japanese. It is, however, still useful for detecting $B c l \mathrm{I}$ polymorphisms, as suggested previously (Antonarakis $e t$ al., 1985; Suzuki et al., 1988). The RFLP frequencies reported by them $(1.2 \mathrm{~kb}$ : $0.9 \mathrm{~kb}=26: 74)$ and this communication $(1.2 \mathrm{~kb}: 0.9 \mathrm{~kb}=33: 67)$ are the same.

St14-1: The fragment sizes were slightly different for the probe St14-1 (2.3 $\mathrm{kb}$ and $1.8 \mathrm{~kb}$ in MspI RFLP, and $4.3 \mathrm{~kb}$ and $4.1 \mathrm{~kb}$ in TaqI RFLP) from those reported previously (Oberle et al., 1985). Some differences were also observed in the incidence of each polymorphic band detected by St14-1. Suzuki et al. (1988) used the St14 probe on the Japanese population, but they did not refer to $\alpha$ and $\beta$ alleles. We report here the incidence for St14-1 RFLPs (alleles 1-8, and $\alpha$ and $\beta$ ). Japanese showed much higher frequencies of alleles 8 and $\beta$ than Caucasians (Table 1). Mandel et al. (1986) suggested that allele $\beta$ is specifically associated with allele 8. We agree with their proposal; all the $X$ chromosome having allele 8 had allele $\beta$ in our study (Fig. 2). The original RFLP probe St14 (9.3 kb fragment) detects $5 \mathrm{MspI}$ alleles (Oberle et al., 1985), but St14-1 we used (3 $\mathrm{kb}$ fragment) can detect only $M s p I$ alleles 3 and 4 . TaqI alleles 4 and 7 were suggested to be associated with $M s p$ I allele 3 and TaqI allele 8 to be associated with $M s p$ I allele 4 . We confirmed that all the $\mathrm{X}$ chromosomes having $T a q \mathrm{I}$ allele 8 have $M s p I$ allele 4.

MN12: The frequency was also significantly different from that reported previously for probe MN12. The PIC value is quite high (0.50) for Japanese population, but is very low for Caucasians $(0.15)$.

Among the probes we used, the expected frequency of heterozygosity among the Japanese females is high (43-50\%) with 36B-2, p114.12 ( $B c l \mathrm{I})$, p43-15, St14-1, $52 \mathrm{~A}, \mathrm{p} 482.6$ and MN12. St14-1 is especially useful as in Caucasians, the frequency being $68 \%$. Other DNA probes on the distal end of X chromosome such as p1.8 (coagulation factor VIII gene-derived) and DX13 (both localized to q28) are reported to be not so useful (frequency of heterozygosity $=18-32 \%$, Suzuki et al., 1988). Moreover, there is no RFLP in Japanese for HPRT gene (localized to q26) or coagulation factor IX gene (located to q26.3-q27.2) in Japanese (Kojima et al., 1987). Therefore, those DNA probes listed above must be quite useful for the linkage analysis in Japan. We would like to perform carrier detection and prenatal diagnosis of ALD by using linkage analysis with these probes. Previous studies have shown a tight linkage between ALD and St14-1 (Aubourg et al., 1987) and also between coagulation factor VIII and St14-1 (Gitschier et al., 1985). Therefore, these probes should also be helpful to identify the defective ALD gene.

Acknowledgments We are grateful to Dr. J. L. Mandel, Dr. K. E. Davies and Dr. P. L. Pearson for their supply of DNA probes. We would like to thank Prof. Ueda (Department of Medical Biochemistry) for his valuable suggestions through this work, and Miss Ohsugi for her technical assistance. 
This study was supported by Grant (No. 62-05-02) from National Center of Neurology and Psychiatry (NCNP) of the Ministry of Health and Welfare of Japan, and was also supported by Grantin-Aid for Scientific Research on Priority Areas, Ministry of Education, Science and Culture of Japan.

\section{REFERENCES}

Antonarakis, S.E., Waber, P.G., Kittur, S.D., Patel, A.S., Kazazian, H.H., Mellis, M.A., Counts, R.B., Stamatoyannopoulos, G., Bowie, E.J.W., Fass, D.N., Pittman, D.D., Wozney, I.M. and Toole, J.J. 1985. Hemophilia A. Detection of molecular defects and carriers by DNA analysis. New Engl. $J$. Med. 313: 842-848.

Aubourg, P.R., Sack, G.H., Meyers, D.A., Lease, J.J. and Moser, H.W. 1987. Linkage of adrenoleukodystrophy to a polymorphic DNA probe. Ann. Neurol. $21: 349-352$.

Gitschier, J., Drayna, D., Tuddenham, E.G.D., White, R.L. and Lawn, R.M. 1985. Genetic mapping and diagnosis of hemophilia A achieved through a $B c /$ polymorphism in the factor VIII gene. Nature 314: 738-740.

Guesella, J.F., Wexler, N.S., Conneally, P.M., Naylor, S.L., Anderson, M.A., Tanzi, R.E., Witkins, P.C., Ottina, K., Wallance, M.R., Sakaguchi, A.Y., Young, A.B., Shoulson, I., Bonilla, E. and Mortin, J.B. 1983. A polymorphic DNA marker genetically linked to Huntington's disease. Nature 306: 234-238.

Kojima, T., Tanimoto, M., Kamiya, T., Obata, Y., Takahashi, T., Ohno, R., Kurachi, K. and Saito, H. 1987. Possible absence of common polymorphisms in coagulation factor IX gene in Japanese subjects. Blood 69: 349-352.

Mandel J.L., Arveiler, B., Camerino, G., Hanauer, A., Heilig, R., Koenig, M. and Oberle, I. 1986. Genetic mapping of human X chromosome: linkage analysis of the $q 26-q 28$ region that includes the fragile $X$ locus and isolation of expressed sequences. Cold Spring Harbor Sym. 51: 195203.

Migeon, B.R., Moser, H.W., Moser, A.B., Axelman, J., Sillence, D. and Norum, R.A. 1981. Adrenoleukodystrophy: Evidence for $X$ linkage, inactivation, and selection favoring the mutant allele in heterozygous celis. Proc. Natl. Acad. Sci. U.S.A. 78: 5066-5070.

Oberle, L., Drayna, D., Camerino, G., White, R. and MandeI, J.L. 1985. The telomeric region of the human $\mathrm{X}$ chromosome long arm: Presence of a highly polymorphic DNA marker and analysis of recombination frequency. Proc. Natl. Acad. Sci. U.S.A. 82: 2824-2828.

Paui, H., Galton, D. and Stocks, J. 1987. DNA polymorphic patterns and haplotype arrangements of the apoA-I, apoC-IIT, apoA-IV gene cluster in different ethnic groups. Hum. Genet. 75: 264-268.

Southern, E.M. 1975. Detection of specific sequence among DNA fragments separated by gel electrophoresis. J. Mol. Biol. 78: 503-517.

Suzuki, N., Nagao, T., and Nakahori, Y. 1988. Carrier detection of Hemophilia A in the Japanese population by use of four intragenic and extragenic RFLPs. Jpn. J. Clin. Hematol. 29: $19-26$.

Tsui, L.-C., Buchwald, M., Barker, D., Braman, J.C., Knowlton, R., Schumm, J.W., Eiberg, H., Mohr, J., Kennedy, D., Plavsic, N., Zsiga, M., Markiewicz, D., Akots, G., Brown, D., Helms, C., Gravius, T., Parker, C., Rediker, K. and Donis-Keller, H. 1985. Cystic fibrosis locus defined by a genetically linked polymorphic DNA marker. Science 230: 1054-1057.

Wainscoat, J.S., Hill, A.V.S., Boyce, A.L., Flint, J., Hernandes, M., Thein, S.L., Old, J.M., Lynch, J.R., Falusi, A.G., Weatherall, D.J. and Clegg, J.B. 1986. Evolutionary relationships of human populations from an analysis of nuclear DNA polymorphisms. Nature 319: 491493.

Wion, K.L., Tuddenham, E.D.G. and Lawn, R.M. 1986. A new polymorphism in the factor VIII gene for prenatal diagnosis of hemophilia A. Nucleic Acids Res. 14: 4535-4542. 